GRAMMER European Spine Journal Award 2017

\section{For Basic and Applied Research}

In order to encourage basic science research in the field of spinal disorders, the European Spine Journal is proud to announce the GRAMMER European Spine Journal Award for Basic Science and Applied Research (20,000 Euro).

This is the highest amount of an award in spinal research, worldwide. Each paper submitted to the Journal dealing with basic science qualifies automatically for this award as soon as it has been published. The winning paper will be selected at the end of each academic year (for the next time in 2016/2017) and will be announced in one of the following issues. The GRAMMER Award will also be presented at the next EUROSPINE meeting. At least one author of the winning paper must attend at his own expense the EUROSPINE 2017 meeting, which is being held in Dublin (Ireland) from October 11-13, to present the paper and receive the award.

The winning paper of the GRAMMER European Spine Journal Award for the best basic science and applied research paper published in the European Spine Journal in the last academic year 2015/2016 has been:

Changes in perfusion and diffusion in the endplate regions of degenerating intervertebral discs: a DCE-MRI study

By Volkan Emre Arpinar,

Scott D. Rand, Andrew P. Klein, Dennis J. Maiman, L. Tugan Muftuler

Eur Spine J (2015) 24:2458-2467

Congratulations from GRAMMER AG, the European Spine Journal and the award committee:

Margareta Nordin, Romorantin, France Max Aebi, Bern, Switzerland Mauro Alini, Davos, Switzerland Dimitris Kletsas, Athens, Greece Kjell Olmarker, Gothenburg, Sweden Hans-Joachim Wilke, Ulm, Germany (Chairman)

\section{Oswestry Disability Index website and translations}

We have established a website for the ODI. One of its functions is to carry validated translations of the instrument for use by non-English speakers. Currently we have versions in 13 languages. We are sure there are others we have not listed. We need to know the version number that has been translated, validation process and any publications that have used it.

Jeremy Fairbank MD FRCS

Paul Pynsent $\mathrm{PhD}$

Nuffield Orthopaedic Centre

Oxford OX3 7LD, UK

Research and Teaching Centre

Royal Orthopaedic Hospital, Birmingham B31 2AP, UK

If readers are aware of other validated translations, please will they contact jeremy.fairbank@ndos.ox.ac.uk

\section{NSpine Congress 2017}

12-15 June 2017

Royal College of Surgeons - London http://nspine.com/congresses/nspine-mainconference-2017/programme/

NSpine - European Spine Journal Collaboration

Research \& Statistics Methodology Sessions June 13, 2017 at NSpine Main Event The Good Reviewer Session June 15, 2017 at NSpine Main Event www.nspine.com

\section{EURASIAN ORTHOPEDIC FORUM 2017}

29-30 June 2017

Moscow, Russia

http://eoforum.ru/en

The Open Operating Theatre (OOT) section of the journal, comprising articles describing surgical procedures with videos as supplementary material, is published exclusively online.

\section{EDUCATION @EUROSPINE}

www.eurospine.org/education

\section{Education Week 2017}

19-23 June 2017

Strasbourg, France

Advanced Course

16-18 October 2017

Strasbourg, France

RESEARCH @EUROSPINE

www.eurospine.org/research

Literature Review Course

21 June 2017

Strasbourg, France

EUROSPINE ANNUAL MEETINGS

www.eurospinemeeting.org

\section{EUROSPINE 2017}

11-13 October 2017

Dublin, Ireland

EUROSPINE Spring

Speciality Meeting 2018

26-27 April 2018

Vienna, Austria

\section{EUROSPINE 2018}

19-21 September 2018

Barcelona, Spain

\section{EUROSPINE 2019}

16-18 October 2019

Helsinki, Finland 